\title{
Stereotactic body radiotherapy for intramedullary metastases: a retrospective series at the Oscar Lambret center and a systematic review
}

\author{
Marion Tonneau ${ }^{1,2^{*}}$, Raphaëlle Mouttet-Audouard ${ }^{1}$, Florence Le Tinier ${ }^{1}$, Xavier Mirabel ${ }^{1}$ and David Pasquier ${ }^{1,3}$
}

\begin{abstract}
Background: Intramedullary metastasis (IMM) is a rare disease with poor prognosis. The incidence of IMMs has increased, which has been linked to improved systemic treatment in many cancers. Surgery and/or radiotherapy are the most commonly used treatments; only small-sample retrospective studies and case reports on stereotactic body radiotherapy (SBRT) have reported acceptable results in terms of local control and clinical improvement, with no reported toxicity. Thus, we performed this monocentric retrospective study on five cases treated with SBRT for IMMs, which we supplemented with a systematic review of the literature.

Methods: We included all patients treated for IMM with SBRT. The target tumor volume, progression-free survival, prescription patterns in SBRT, survival without neurological deficit, neurological functional improvement after treatment, and overall survival were determined. Results: Five patients treated with a median dose of $30 \mathrm{~Gy}$ in a median number of fractions of 5 (prescribed at a median isodose of 86\%) included. The median follow-up duration was 23 months. Two patients showed clinical improvement. Three patients remained stable. Radiologically, 25\% of patients had complete response and 50\% had stable disease. No significant treatment-related toxicity was observed. Conclusion: SBRT appears to be a safe, effective, and rapid treatment option for palliative patients.
\end{abstract}

Keywords: Radiotherapy, Stereotactic, Radiosurgery, SBRT, Intramedullary metastasis, Neuro-oncology

\section{Introduction}

The development of intramedullary metastases (IMMs) is a rare event, and IMMs account for $4.2-8.5 \%$ of central nervous system metastases [1]. However, improved survival owing to more effective treatments for many cancers is reflected in the increased incidence of IMM. More than half of all cases of IMMs are secondary to lung cancer (54\%), breast cancer (11\%), renal carcinoma

\footnotetext{
* Correspondence: marion.tonneau@gmail.com

'Département Universitaire de Radiothérapie - Centre Oscar Lambret, Lille, France

${ }^{2}$ Centre de Recherche du Centre Hospitalier Universitaire de Montréal (CRCH UM), Qc, Montréal, Canada

Full list of author information is available at the end of the article
}

(9\%), melanoma (8\%), or lymphoma (4\%) [1]. These lesions can appear at any time in the history of the oncological disease and can affect the medulla. Because of the low number of lesions treated, therapeutic standards are not clearly defined. Neurosurgery and microsurgical techniques are one of the few available treatments because of their advancements. The application of stereotactic body radiation therapy (SBRT) in the management of spinal lesions has recently emerged, and it was initially used to treat vertebral metastases [2]. It is now considered a safe and effective option [3, 4]. Issues related to myelopathy and radiation-induced spinal cord (SC) injury have historically limited the application of SBRT in treating intramedullary lesions $[5,6]$. Thus,

(c) The Author(s). 2021 Open Access This article is licensed under a Creative Commons Attribution 4.0 International License, which permits use, sharing, adaptation, distribution and reproduction in any medium or format, as long as you give appropriate credit to the original author(s) and the source, provide a link to the Creative Commons licence, and indicate if changes were made. The images or other third party material in this article are included in the article's Creative Commons licence, unless indicated otherwise in a credit line to the material. If material is not included in the article's Creative Commons licence and your intended use is not permitted by statutory regulation or exceeds the permitted use, you will need to obtain permission directly from the copyright holder. To view a copy of this licence, visit http://creativecommons.org/licenses/by/4.0/ The Creative Commons Public Domain Dedication waiver (http://creativecommons.org/publicdomain/zero/1.0/) applies to the data made available in this article, unless otherwise stated in a credit line to the data. 
there are very few studies on the application of radiosurgery for IMM, and management guidelines have not yet been standardized [7]. In this study, we performed a monocentric retrospective evaluation of the SBRT management of IMM in five patients who were treated with SBRT for IMMs to assess local control and progressionfree survival (PFS).

\section{Materials and methods}

\section{Systematic review}

First, we conducted a systematic review of the literature based on the Preferred Reporting Items for Systematic Review and Meta-Analyses (PRISMA) selection method. A systematic review of the scientific literature was conducted using the PubMed, MEDLINE, and Google Scholar databases. The following keywords were used to perform the search: "Radiosurgery," OR "Stereotactic Radiotherapy," OR "SBRT," OR "SABR," OR "Stereotactic Body Radiotherapy," OR "Stereotactic Body Radiation Therapy," AND, "Intra-Medullary Metastasis," OR "Intra-Medullary Spinal Metastasis," OR "Intra-Medullary Spinal Cord Metastasis." No date limit was set. The inclusion criteria were (1) prospective or retrospective studies or case reports, (2) studies including patients with IMM, (3) studies that used SBRT, (4) local control (LC) and PFS reported as the primary or secondary endpoint, and (5) articles published in English or French. The exclusion criteria were (1) use of non-SBRT or hypofractionated radiotherapy, (2) primary intramedullary lesions, and (3) series evaluating only reirradiation. Information of the following variables was extracted from the studies: type of study, number of patients, total dose delivered, number of fractions, LC at 5 years, clinical and radiological results, and possible toxicities. A flowchart showing the process for the search and selection of the articles is detailed in Fig. 1.

\section{Population}

We retrospectively analyzed patients treated with SBRT for IMM at the Oscar Lambret Center (Lille, France). Five patients were treated between October 2014 and March 2020. The eligibility criteria for their inclusion were as follows: age $>18$ years, histologically proven primary cancer, a World Health Organization performance status of $\leq 2$, received SBRT as an ablative therapy using a CyberKnife ${ }^{\bullet}$ linear robotic accelerator, and no previous surgery or radiation therapy for the SC. The cases were discussed by a multidisciplinary team, in consultation with the neurosurgeon, radiation oncologist, and medical oncologist. All patients were treated for IMMs, with the primary goal of symptom palliation or to maximize LC. All patients were treated with SBRT.

\section{SBRT planning}

All treatments were delivered using a high-precision CyberKnife $^{\bullet}$ linear accelerator with 6-MV photons. Treatment simulation was performed using a computed

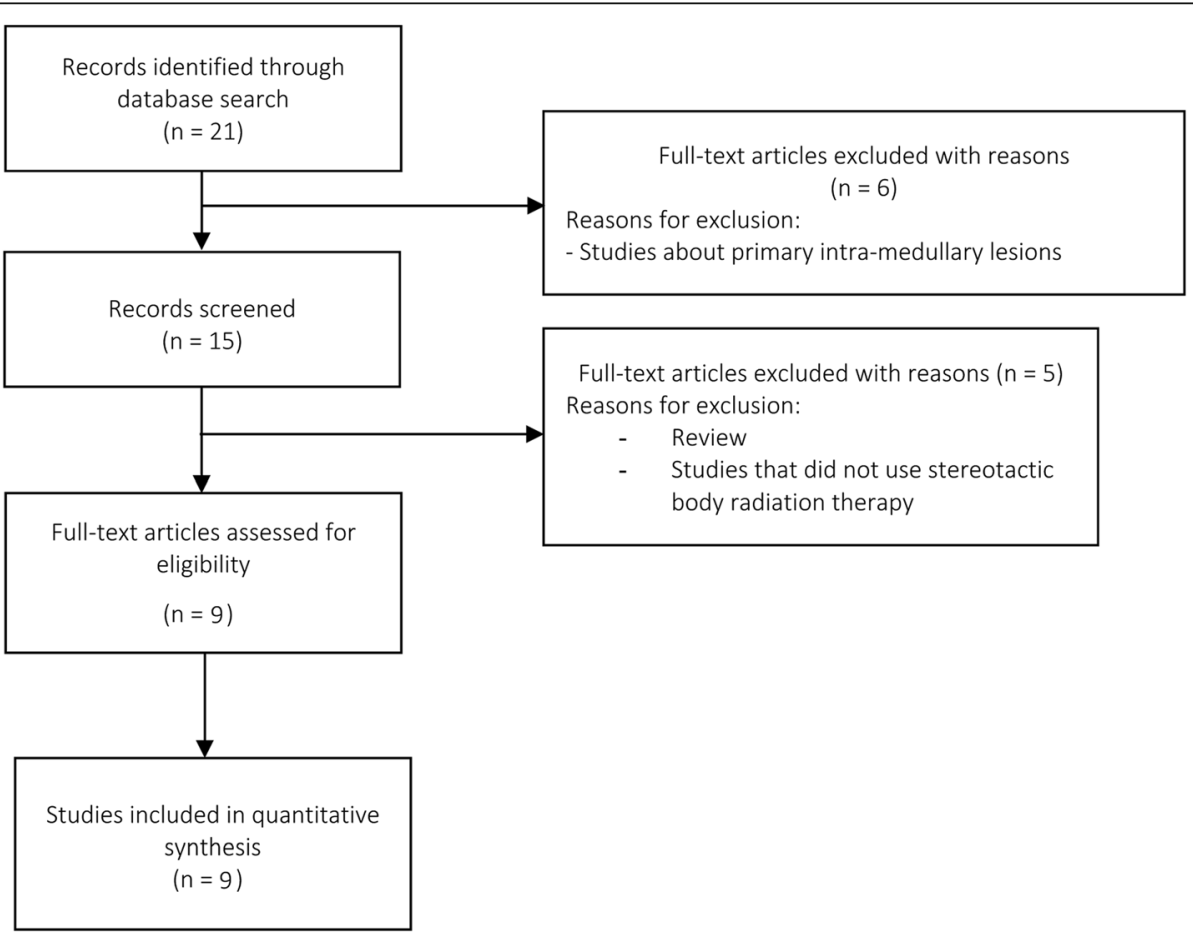

Fig. 1 Flowchart showing the process for search and selection of articles 
tomography (CT) simulator with millimeter-thickness. The target tumor volume and critical organs, such as the $\mathrm{SC}$, were then determined. Dosimetric parameters were reported according to the ICRU 91 recommendations [8].

\section{Follow-up and evaluation of response to SBRT}

The observation time started in the first fraction of the SBRT. The primary endpoint was PFS, defined as the absence of progression at the treatment site according to the RECIST criteria. The secondary endpoints were the description of survival without neurological deficit, description of neurological functional improvement after treatment, and overall survival (OS). The first clinical follow-up was done at one month. The first radiologic reassessment occurred at three months then every three months. The follow-up was left to the physician's choice, by CT scan and/or Magnetic Resonance Imaging (MRI), depending on the clinical context.

\section{Ethics approval}

Clear and fair information was provided to all patients according to the recommendations of the Reference Methodology MR-004, which was related to the processing of personal data implemented in the context of research not involving humans, studies, and evaluations in the field of health, on May 3, 2018.

\section{Statistical analysis}

Clinical and dosimetric characteristics were described according to the classical rules of descriptive statistics. In view of the small number of patients, the statistical analysis was essentially descriptive, and no tests were performed. Dosimetry parameters were described in terms of median, extremes, mean, and standard deviation for quantitative data and in terms of frequency and percentage for qualitative data.

\section{Results}

\section{Systematic review}

We identified 9 articles reporting on the treatment of intramedullary metastasis by means of SBRT. Of these, six were case reports [9-14], and three were larger case series [15-17]. Fifty-four patients with a total of 69 intramedullary metastases were included in the analysis. The most common histologies were breast carcinoma $(n=21)$, non-small cell lung cancer $(n=8)$, and clear cell renal carcinoma $(n=3)$ (see Table 1$)$. Of the 69 IMMs, $31(45 \%)$ were in the cervical spinal cord, 25 (36\%) spanned over the thoracic cord, 12 (17\%) were lumbar et one $(1,5 \%)$ was located at the conus medullaris. Only four papers [13,15-17] reported the tumor volume, with a mean value of $0.99 \mathrm{~cm}^{3}$. Most of the lesions were treated by means of CyberKnife ${ }^{\circ}$ (90\%), followed by seven (10\%) lesions having undergone treatment with LINAC. Radiation total doses ranged from 14 to $39 \mathrm{~Gy}$. Regarding fractionation, they range between 1 to 13

Table 1 Systematic review of IMM studies wherein patients were treated with SBRT

\begin{tabular}{|c|c|c|c|c|c|}
\hline $\begin{array}{l}\text { Author and } \\
\text { year }\end{array}$ & $\begin{array}{l}\text { Study } \\
\text { design }\end{array}$ & $\begin{array}{l}\text { Number } \\
\text { of } \\
\text { patients }\end{array}$ & $\begin{array}{l}\text { Number of } \\
\text { MIM } \\
\text { treated }\end{array}$ & Histology & MIMs location \\
\hline $\begin{array}{l}\text { Shin, } 2009 \\
{[15]}\end{array}$ & Retrospective & 6 & 6 & $\begin{array}{l}\text { Melanoma }(n=1) \text {, Breast carcinoma }(n=1) \text {, Breast invasive ductal cell } \\
\text { carcinoma }(n=1) \text {, renal cell carcinoma }(n=1) \text {, non-small cell lung } \\
\text { cancer }(n=1) \text {, glioma }(n=1)\end{array}$ & $\begin{array}{l}\text { Cervical }(n=5) \\
\text { Thoracic }(n=1)\end{array}$ \\
\hline $\begin{array}{l}\text { Parikh, } \\
2009[9]\end{array}$ & Case report & 1 & 1 & Renal cell carcinoma & Cervical \\
\hline $\begin{array}{l}\text { Dewas, } \\
2011[10]\end{array}$ & Case report & 1 & 1 & Pleural mesothelioma & Thoracic \\
\hline $\begin{array}{l}\text { Lieberson, } \\
2012[11]\end{array}$ & Case report & 1 & 1 & Prostate carcinoma & Conus Medullaris \\
\hline $\begin{array}{l}\text { Veeravagu, } \\
2012[16]\end{array}$ & Retrospective & 9 & 11 & $\begin{array}{l}\text { Breast carcinoma }(n=5) \text {, non-small cell lung cancer }(n=2) \text {, teratoma } \\
(n=1) \text {, Breast infiltrating ductal epithelioid }(n=1)\end{array}$ & $\begin{array}{l}\text { Cervical }(n=7) \\
\text { Thoracic }(n=3) \\
\text { Lumbar }(n=1)\end{array}$ \\
\hline $\begin{array}{l}\text { Mori et al., } \\
2016[12]\end{array}$ & Case report & 1 & 1 & Papillary thyroid carcinoma & Cervical \\
\hline $\begin{array}{l}\text { Garcia, } \\
2016[13]\end{array}$ & Case report & 1 & 1 & Breast ductal carcinoma & Cervical \\
\hline $\begin{array}{l}\text { Barrie, } \\
2019[14]\end{array}$ & Case report & 1 & 1 & Renal Cell Carcinoma & Cervical \\
\hline $\begin{array}{l}\text { Ehret, } 2021 \\
\text { [17] }\end{array}$ & Retrospective & 33 & 46 & $\begin{array}{l}\text { Breast carcinoma }(n=16) \text {, lung cancer }(n=4) \text {, malignant melanoma } \\
(n=3) \text {, others }(n=10)\end{array}$ & $\begin{array}{l}\text { Cervical }(n=15) \text {, } \\
\text { Thoracic }(n=20) \text {, } \\
\text { Lumbar }(n=11)\end{array}$ \\
\hline
\end{tabular}


fractions. Treatment outcomes were favorable in most of the studies, with improvement [9, 12, 13, 15-17] or stable symptoms [10, 11, 14-17]. Tumor stabilization or decrease in size was observed in most of the studies [11, 12, 15-17]. In all the papers, clinical and radiological stabilization or improvement was described. Reported OS ranged from 2 to 15 months. No treatment-related complications have been reported. All these data are available in Table 2.

\section{Our study}

\section{Patients' characteristics}

Patient characteristics are summarized in Table 3. All patients who met the inclusion criteria were included in the study, leading to a total of five patients. The median age was 67 years (range, 33-72 years). Primary cancers were lung adenocarcinoma, malignant melanoma, breast cancer and renal cell carcinoma. Two patients with lung adenocarcinoma were both EGFR negative, ALK negative and KRAS negative. For one of them, PD-L1 expression was $70 \%$. All patients except one had brain and extracerebral metastasis at the time of treatment of the IMM. Two patients had concomitant systemic therapy. One patient had NIVOLUMB for a metastatic melanoma. The other one had TRASTUZUMAB PERTUZUMAB for a metastatic breast cancer. The other one didn't have concomitant systemic treatment (see Table 3).

One cervical lesion, one lumbar lesion, and three thoracic lesions were treated. The median interval from the diagnosis of the primary cancer to the diagnosis of IMM was 66.2 months (range: 19.2-178.8) months.

Two patients initially had paraplegia (complete for one patient), one patient had posterior cord syndrome, and the other two patients did not present with symptoms. Corticosteroid use was reported only for two patients (patients 3 and 5) who received $1 \mathrm{mg} / \mathrm{kg}$ for 2 weeks and a progressive decrease. The median delay between diagnostic of MIM to start of the radiotherapy was 21 days (6-44 days). The two patients with the longer delay didn't have any neurologic symptoms (33 and 44 days) (see Table 3). The average tumor volume was $1.4 \mathrm{cc}$ (standard deviation $0.91 \mathrm{cc}$ ), and the largest volume was 2.74 cc (see Table 4).

\section{Dosimetry planning}

All patients underwent planning CT without intravenous contrast and planning MRI. This MRI was used to aid in the delineation of the macroscopic tumor lesion. The GTV was contoured on the CT-scan with a fusion on contrast-enhanced MRI T1 sequence. No additional margin was added for microscopic spread of disease. A

Table 2 General characteristics IMM studies wherein patients were treated with SBRT

\begin{tabular}{|c|c|c|c|c|c|c|c|c|}
\hline $\begin{array}{l}\text { Author and } \\
\text { year }\end{array}$ & $\begin{array}{l}\text { Mean tumor } \\
\text { volume in cubic } \\
\text { centimeter }\end{array}$ & $\begin{array}{l}\text { Treatment } \\
\text { modality }\end{array}$ & Dose/fraction & $\begin{array}{l}\text { Median } \\
\text { follow- } \\
\text { up }\end{array}$ & $\begin{array}{l}\text { Overall } \\
\text { survival }\end{array}$ & Clinical outcome & Radiological outcome & Toxicities \\
\hline $\begin{array}{l}\text { Shin, } 2009 \\
\text { [15] }\end{array}$ & 1.52 & LINAC & $\begin{array}{l}14 \text { Gy (10-16 } \\
\text { Gy) / } 1 \text { fraction }\end{array}$ & $\begin{array}{l}10 \\
\text { months }\end{array}$ & $\begin{array}{l}8(2-19) \\
\text { months }\end{array}$ & $\begin{array}{l}\text { Improvement: } 80 \% \text {, } \\
\text { Stable: } 10 \% \text {, Worse: } \\
10 \%\end{array}$ & $\begin{array}{l}\text { Complete: } 22 \% \text {, Partial: } \\
\text { 33\%, Stable: } 33 \% \\
\text { Progression: } 11 \%\end{array}$ & None \\
\hline $\begin{array}{l}\text { Parikh, } \\
2009[9]\end{array}$ & NA & CK & $\begin{array}{l}15 \mathrm{~Gy} / 3 \\
\text { fractions }\end{array}$ & $\begin{array}{l}26 \\
\text { months }\end{array}$ & $\begin{array}{l}9,8 \\
\text { months }\end{array}$ & Improvement & Stable & None \\
\hline $\begin{array}{l}\text { Dewas, } \\
2011[10]\end{array}$ & NA & CK & $\begin{array}{l}20 \text { Gy / } 4 \\
\text { fractions }\end{array}$ & $\begin{array}{l}11 \\
\text { months }\end{array}$ & $N R$ & Stable & Stable & None \\
\hline $\begin{array}{l}\text { Lieberson, } \\
2012 \text { [11] }\end{array}$ & NA & CK & $\begin{array}{l}27 \text { Gy / } 3 \\
\text { fractions }\end{array}$ & $\begin{array}{l}3 \\
\text { months }\end{array}$ & $\begin{array}{l}15 \\
\text { months }\end{array}$ & Stable & Complete & None \\
\hline $\begin{array}{l}\text { Veeravagu, } \\
2012[16]\end{array}$ & 1.17 & CK & $\begin{array}{l}21 \text { Gy }(14-27 \\
\text { Gy) / } 3 \\
\text { fractions }(1-5)\end{array}$ & $N R$ & $\begin{array}{l}2 \\
\text { months }\end{array}$ & $\begin{array}{l}\text { Improvement: 11\%, } \\
\text { Stable: } 44 \%, \text { NA: } \\
55 \%\end{array}$ & $\begin{array}{l}\text { Partial: 22\%, Stable: 22\%, } \\
\text { NA: } 78 \%\end{array}$ & None \\
\hline $\begin{array}{l}\text { Mori et al., } \\
2016 \text { [12] }\end{array}$ & NA & VMAT & $\begin{array}{l}39 \text { Gy / } 13 \\
\text { fractions }\end{array}$ & $\begin{array}{l}5 \\
\text { months }\end{array}$ & $N R$ & Improvement & Partial & None \\
\hline $\begin{array}{l}\text { Garcia, } \\
2016[13]\end{array}$ & 0.167 & CK & $\begin{array}{l}17 \text { Gy / } 1 \\
\text { fraction }\end{array}$ & $\begin{array}{l}37 \\
\text { months }\end{array}$ & $\begin{array}{l}8 \\
\text { months }\end{array}$ & Improvement & Stable & None \\
\hline $\begin{array}{l}\text { Barrie, } \\
2019[14]\end{array}$ & NA & CK & $\begin{array}{l}25 \mathrm{~Gy} / \mathrm{5} \\
\text { fractions }\end{array}$ & $\begin{array}{l}26 \\
\text { months }\end{array}$ & $\begin{array}{l}8 \text { (0-65) } \\
\text { months }\end{array}$ & Stable & Progression & None \\
\hline $\begin{array}{l}\text { Ehret, } 2021 \\
{[17]}\end{array}$ & 1.1 & CK & $\begin{array}{l}16 \text { Gy (6-24 Gy) } \\
\text { / } 1 \text { fraction ( } 1- \\
\text { 3) }\end{array}$ & $\begin{array}{l}8.5 \\
\text { months }\end{array}$ & $\begin{array}{l}11,7 \\
\text { months }\end{array}$ & $\begin{array}{l}\text { Improvement: } 27 \% \text {, } \\
\text { Stable: } 30 \% \text {, Worse: } \\
21 \%\end{array}$ & $\begin{array}{l}\text { Complete: } 79 \% \text { patients } \\
\text { with follow-up imaging }\end{array}$ & None \\
\hline $\begin{array}{l}\text { Our series, } \\
2021\end{array}$ & & CK & $\begin{array}{l}30 \text { Gy }(25-36 \\
\text { Gy) / } 6 \\
\text { fractions (5-6) }\end{array}$ & $\begin{array}{l}23 \\
\text { months }\end{array}$ & $N R$ & $\begin{array}{l}\text { Improvement: } 40 \% \text {, } \\
\text { Stable: } 60 \%\end{array}$ & $\begin{array}{l}\text { Complete: } 25 \% \text {, Partial: } \\
\text { 50\%, Stable: } 25 \%\end{array}$ & None \\
\hline
\end{tabular}


Table 3 Patients' characteristics

\begin{tabular}{|c|c|c|c|c|c|c|c|c|c|c|c|}
\hline $\begin{array}{l}\text { No. of } \\
\text { patients }\end{array}$ & $\begin{array}{l}\text { Age } \\
\text { (years) }\end{array}$ & Sex & WHO* & Primary cancer & $\begin{array}{l}\text { Mutations } \\
\text { and } \\
\text { Biomarkers }\end{array}$ & $\begin{array}{l}\text { Concomitant } \\
\text { systemic } \\
\text { medication }\end{array}$ & Level & $\begin{array}{l}\text { Presenting } \\
\text { symptoms }\end{array}$ & $\begin{array}{l}\text { Muscular } \\
\text { strength } \\
\text { at } \\
\text { diagnosis }\end{array}$ & $\begin{array}{l}\text { Use of } \\
\text { corticosteroids }\end{array}$ & $\begin{array}{l}\text { Time } \\
\text { between } \\
\text { diagnostic to } \\
\text { start of SBRT } \\
\text { (days) }\end{array}$ \\
\hline 1 & 67 & M & $2-3$ & $\begin{array}{l}\text { Lung, } \\
\text { adenocarcinoma }\end{array}$ & $\begin{array}{l}\text { EGFR- / } \\
\text { ALK- } \\
\text { PD-L1 70\% }\end{array}$ & No & $\mathrm{T} 10$ & $\begin{array}{l}\text { Total } \\
\text { paraplegia }\end{array}$ & $0 / 5$ & No & 14 \\
\hline 2 & 69 & $\mathrm{~F}$ & 1 & $\begin{array}{l}\text { Lung, } \\
\text { adenocarcinoma }\end{array}$ & $\begin{array}{l}\text { EGFR- / } \\
\text { ALK- / } \\
\text { KRAS- }\end{array}$ & No & $\mathrm{T} 11$ & $\begin{array}{l}\text { Posterior } \\
\text { cord } \\
\text { syndrome }\end{array}$ & $4 / 5$ & No & 21 \\
\hline 3 & 72 & M & 2 & $\begin{array}{l}\text { Kidney, clear cell } \\
\text { carcinoma }\end{array}$ & $x$ & No & L2 & $\begin{array}{l}\text { Partial } \\
\text { paraplegia }\end{array}$ & $3 / 5$ & Yes (1 mg/kg) & 6 \\
\hline 4 & 33 & M & 0 & Skin, melanoma & $x$ & NIVOLUMAB & T8 & None & $5 / 5$ & No & 33 \\
\hline 5 & 62 & $\mathrm{~F}$ & 1 & $\begin{array}{l}\text { Breast, } \\
\text { adenocarcinoma }\end{array}$ & $\begin{array}{l}\text { HER }+++ \text { I } \\
\text { HR }+\end{array}$ & $\begin{array}{l}\text { TRASTUZUMAB } \\
\text { PERTUZUMAB }\end{array}$ & C4 & None & $5 / 5$ & Yes (1 mg/kg) & 44 \\
\hline
\end{tabular}

*World Health Organization (WHO) at the diagnosis of metastasis

Abbreviation: HR: Hormonal Receptors

Planning Target Volume (PTV) margin of $1 \mathrm{~mm}$ was added to the GTV. A thermoformed mask was used for immobilization. No PRV was used for OAR. Dose was prescribed to 73 to $85 \%$, except for patient one whose prescription was more homogeneous (isodose 97\%) due to the infiltrating nature of the tumor which encompassed the entire circumference of the spinal cord. All patients were treated in the supine position. The median total dose delivered was $30 \mathrm{~Gy}$. Among the five patients, two were irradiated using a dose of 36 Gy delivered in six fractions, two others, a dose of $30 \mathrm{~Gy}$ in six fractions, and the last one, a dose of $25 \mathrm{~Gy}$ in five fractions. The fractionation scheme was left to the discretion of the physician. These are hypofractionation schemes commonly used in other clinical situations. All patients were treated on alternate days. The median biologically effective dose (BED) was $45 \mathrm{~Gy}$, assuming $\alpha / \beta=10$, and ranging from $37.5 \mathrm{~Gy}$ for $5 \times 5$ Gy to $57.40 \mathrm{~Gy}$ for the $6 \mathrm{~Gy}$ $\times 6$ fraction schedule. The SBRT treatment schedule and dosimetry characteristics are presented in Table 5.

\section{Clinical outcome}

The median follow-up period was 23 months (range: 15.4-72 months). OS was heterogeneous between patients, ranged for 5,9 to 72 months. The OS is presented in Fig. 2. The median OS was not reach. Clinical and radiological outcomes are presented in Table 6.

Follow-up At the end of our study, three patients were still alive, and two patients died of disease progression. No deaths related to the treatment were reported. None of the patients relapsed locally. Two patients presented with distant progression.

Radiological response Radiological response to SBRT was evaluated in three patients at 3 months. Two were reassessed with CT and one was reassessed with MRI, according to RECIST criteria. Among these three patients, one had complete response (total dose $30 \mathrm{~Gy}$ in $6 \times 5 \mathrm{~Gy}$ ), one had near-complete response (30 Gy in $6 \times$ 5 Gy) (see Fig. 3), and one had lesion stability ( 25 Gy in $5 \times 5$ Gy).

For one patient, no dedicated radiological follow-up of the intramedullary lesion was obtainable. This patient was evaluated for the first time, 18 months after treatment, using MRI. This patient had partial response (36 Gy in $6 \times 6$ Gy) at 18 months.

The last patient died within 3 months of treatment and wasn't evaluated. The patient who had nearcomplete response at 3 months, had a complete response on MRI, according to RECIST criteria, at one year.

Table 4 Treatment characteristics

\begin{tabular}{|c|c|c|c|c|c|c|c|}
\hline No. of patients & Total dose (Gy) & Number of fractions & Fraction (Gy) & BED $(\alpha / ß=10)(G y)$ & $\operatorname{BED}(a / \beta=2)(G y)$ & GTV (cc) & PTV (cc) \\
\hline 1 & 30 & 6 & 5 & 45 & 105.0 & 1.72 & 2.62 \\
\hline 2 & 36 & 6 & 6 & 57.60 & 144.0 & 1.16 & 1.95 \\
\hline 3 & 25 & 5 & 5 & 37.50 & 87.5 & 2.74 & 5.27 \\
\hline 4 & 36 & 6 & 6 & 57.60 & 144.0 & 0.31 & 0.62 \\
\hline 5 & 30 & 6 & 5 & 45 & 105.0 & 1.0 & 1.58 \\
\hline
\end{tabular}

Abbreviations: Gy, gray; cc, cubic centimeter; BED, biologically effective dose 
Table 5 Dosimetry parameters

\begin{tabular}{lllllllllll}
\hline $\begin{array}{l}\text { No. Of } \\
\text { patients }\end{array}$ & $\begin{array}{l}\text { Near } \\
\text { Max }(G y)\end{array}$ & $\begin{array}{l}\text { Near } \\
\text { Min }(G y)\end{array}$ & $\begin{array}{l}\text { D50\% } \\
\text { (Gy) }\end{array}$ & $\begin{array}{l}\text { D98\% } \\
\text { GTV (Gy) }\end{array}$ & $\begin{array}{l}\text { D95\% } \\
\text { PTV (Gy) }\end{array}$ & $\begin{array}{l}\text { D99\% } \\
\text { PTV (Gy) }\end{array}$ & $\begin{array}{l}\text { Prescription } \\
\text { isodose (\%) }\end{array}$ & $\begin{array}{l}\text { D2\%_Spinal_ } \\
\text { Cord (Gy) }\end{array}$ & $\begin{array}{l}\text { D98\%_Spinal_ } \\
\text { Cord (Gy) }\end{array}$ & $\begin{array}{l}\text { D50\%_SPinal_ } \\
\text { Cord (Gy) }\end{array}$ \\
\hline $\mathbf{1}$ & 30.7 & 28.8 & 30.0 & 29.5 & 29.1 & 28.5 & 97 & 30.6 & 0.2 & 13.6 \\
$\mathbf{2}$ & 44.5 & 20.8 & 38.8 & 26.4 & 22.8 & 20.0 & 80 & 13.9 & 0.7 & 0.8 \\
$\mathbf{3}$ & 29.1 & 25.1 & 27.1 & 26.6 & 25.3 & 25.0 & 85 & 19.7 & 0.1 & 0.2 \\
$\mathbf{4}$ & 42.1 & 27.8 & 35.8 & 32.4 & 28.9 & 26.7 & 85 & 2.8 & 0.3 & 0.4 \\
$\mathbf{5}$ & 41.5 & 24.1 & 33.5 & 28.6 & 24.7 & 23.6 & 73 & 24.4 & 0.02 & 0.4 \\
\hline
\end{tabular}

Abbreviations: Gy, gray; Dx\%, dose received in x\% of the volume; Near_Max: dose received in 2\% of the PTV; Near_Min: dose received in 98\% of the PTV

Clinical response At the first clinical evaluation three patients were stable, and two patients showed functional improvement. The patient with a complete motor deficit did not show clinical recovery during the first reassessment. Only one patient, with partial paraplegia, had complete recovery of motor function. This patient had been treated with $25 \mathrm{~Gy}$ in fractions of $5 \mathrm{~Gy}$. The patient who presented with complete recovery of his sensory function had been treated with the $36 \mathrm{~Gy}$ in 6 fractions schedule.

\section{Toxicities}

None of the patients experienced worsening of neurological symptoms during the treatment. The most common side effect was asthenia grade $1 / 2 \quad(n=2)$. This occurred during treatment and in the following days. None of the patients developed radiation necrosis, bleeding, myelopathy, acute, or delayed treatment-related complications $\geq$ grade 1 .

\section{Discussion}

In this study, we reported the outcomes of a series of patients treated with SBRT for IMM. Despite the small number of patients, a variety of primary histologies, and different treatment patterns, we reported partial or complete radiological responses in all radiologically reevaluated patients and two clinical improvements (motor deficit), including complete recovery of neurological function with no toxicity.

Three objectives must be considered in the management of these patients: 1) to achieve LC of the tumor to prevent or treat neurological symptomatology, 2) to avoid morbidity in patients who are frequently in palliative care, with limited survival, and 3) to propose a treatment plan adapted to the patient's general condition. Thus, early diagnosis is important to increasing patient survival and minimizing morbidity. Consequently, the justification of radiosurgery seems attractive in this clinical context. Currently, surgery can be proposed for patients not presenting with distant metastasis, and a histopathological diagnosis is needed $[1,18]$. LC after surgical resection is acceptable, but surgery may be responsible for the worsening of neurological symptoms [19]. Currently, there is no standardized SBRT-based treatment for the treatment of IMMs. Several studies have been published on the application of surgery, radiotherapy, or radiosurgery, such as case reports or retrospective studies with a limited number of patients [9-17] (see Table 1). These studies have reported very

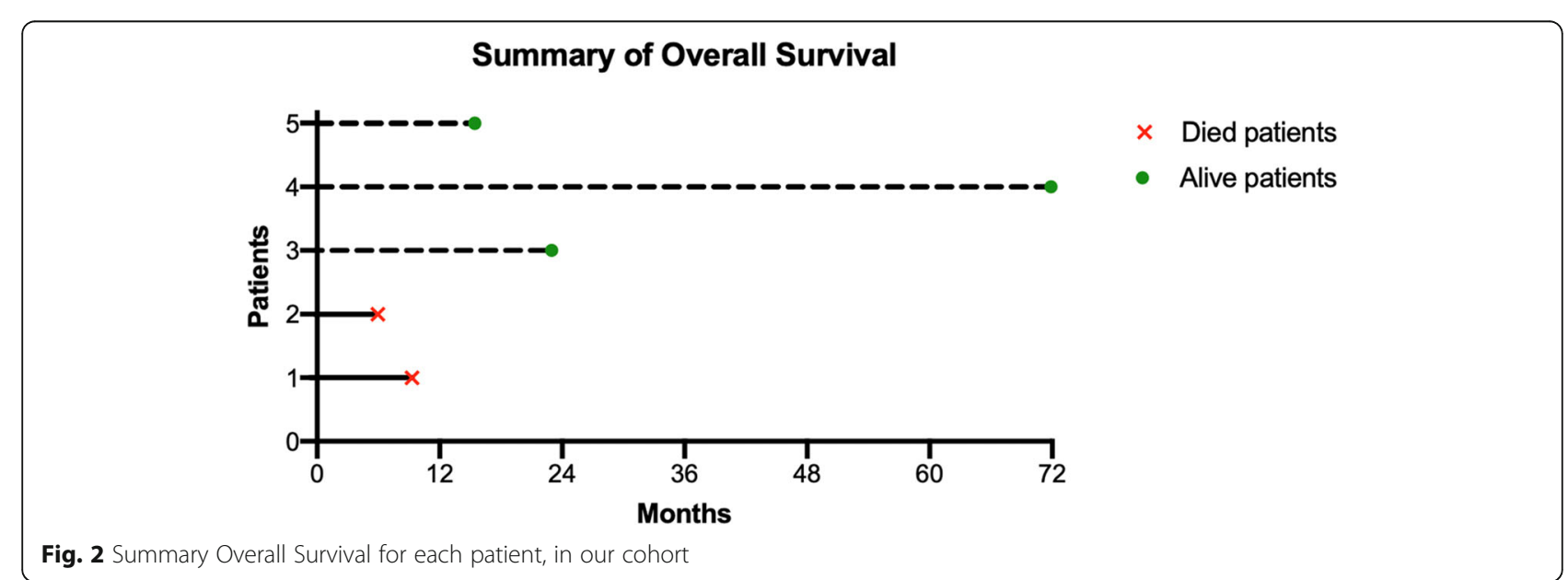


Table 6 Clinical and radiological outcomes at first evaluation

\begin{tabular}{llllllll}
\hline $\begin{array}{l}\text { No. Of } \\
\text { patients }\end{array}$ & $\begin{array}{l}\text { Time to first } \\
\text { evaluation }\end{array}$ & $\begin{array}{l}\text { Type of } \\
\text { imaging }\end{array}$ & $\begin{array}{l}\text { Motor } \\
\text { deficit }\end{array}$ & Sensory deficit & $\begin{array}{l}\text { Clinical } \\
\text { response }\end{array}$ & $\begin{array}{l}\text { Imaging } \\
\text { Radiological } \\
\text { response }\end{array}$ \\
\hline $\mathbf{1}$ & 3 months & Scanner & 0 & $\begin{array}{l}\text { Posterior cord syndrome L1 } \\
\text { L-T12 R }\end{array}$ & Stability & Scan & Complete response \\
$\mathbf{2}$ & NA & NA & 4 & None & Improvement & None & NA \\
$\mathbf{3}$ & 3 months & Scanner & 5 & None & Improvement & Scan & Stability \\
$\mathbf{4}$ & 18 months & MRI & 5 & None & Stability & MRI & Partial response \\
$\mathbf{5}$ & 3 months & MRI & 5 & None & Stability & MRI & Almost complete \\
& & & & & & & response
\end{tabular}

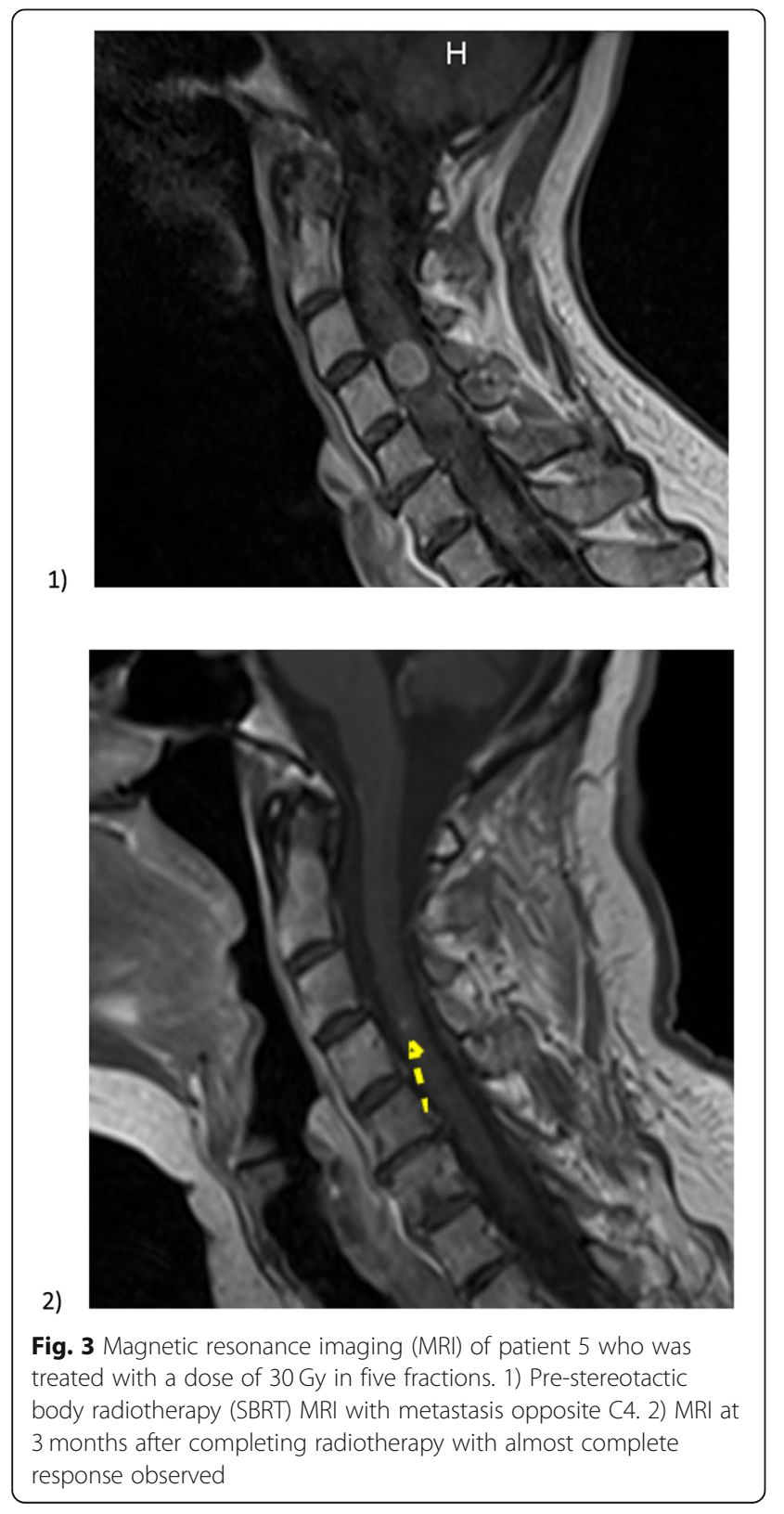

heterogeneous fractionations adapted to the patient's irradiation history, tumor radiosensitivity, or local practices (Table 2).

Typically, oligometastatic patients in whom the primary pathology is controlled [19, 20], and with significant or complete neurological deficits are managed surgically $[1,21]$. In our review, the tumor volume of treated IMMs averaged $0.9 \mathrm{cc}[13,15-17]$. The median tumor volume in our study was $1.4 \mathrm{cc}$ (range: $0.31-2.74$ cc), compared to $0.7 \mathrm{cc}$ (range: $0.1-5.8 \mathrm{cc}$ ) in the study by Ehret et al. However, the patient with the largest tumor volume in our study, i.e., $2.74 \mathrm{cc}$, had partial paraplegia evaluated at $3 / 5$ and experienced complete recovery of his symptoms. In our cohort, one patient presented with complete paraplegia and was treated with SBRT, to improve neurological functional signs. The general condition and medical contraindications of this patient did not allow for surgical management. The patient died within 9 months of treatment, with no improvement in symptoms. Radiosurgery seems to be most effective in patient who are diagnosed early, with a controlled primary disease, and who present without or minimal neurological symptoms [22, 23].

Studies evaluated in our review have reported heterogeneous treatment patterns. Most studies published in the literature have used a single fraction [13, 15-17] or 3 fraction regimens $[9,11,17]$. In our study, four patients $(80 \%)$ were treated in six fractions, and one patient was treated in five fractions. Ehret et al. delivered a median total dose of 16 Gy (range: 6-24 Gy) in 1-3 fractions, in mostly single sessions (91\%). They reported LC in 64 and $73 \%$ at 12 and 24 months, respectively. Four patients (12\%) died within 2 months of treatment, from metastatic disease progression [17]. To our knowledge, there are no published data, that have evaluated conventional palliative radiotherapy in the management of IMMs. The treatment regimens found in the literature and performed in our study were different from those performed in palliative radiotherapy (8 Gy in 1 fraction, 20 Gy in 5 fractions, 30 Gy in 10 fractions). In palliative radiotherapy for uncomplicated bone metastasis, the single dose is the regimen of choice [24]. In the case of 
large soft tissue mass in contact with the bone metastasis, high dose fractionated regimens are recommended [25]. Even if the results are equivalent, the international consensus suggests that single sessions are preferred. SBRT in a single fraction may be an option for patients with IMMs in palliative care, with an altered general condition, in whom it may be necessary to reduce the overall duration of treatment. Nevertheless, previous studies have shown that fractionation increases SC tolerance; however, the optimal balance is not yet known [5]. The higher dose and intra-tumor dose heterogeneity gives rise to the expectation of greater and more durable efficacy. Finally, the cost-effectiveness compared to standard palliative radiotherapy is difficult to assess in this context.

Shin et al. reported that in 9 patients treated (11 IMMs), with a median dose of 14 Gy (range: 10-16 Gy), in 1 fraction, clinical improvement was observed in $80 \%$ of patients. They observed complete imaging response in $22 \%$ of these patients and partial response in 33\%. The median $\mathrm{BED}_{10}(\alpha / \beta=10)$ was $33 \mathrm{~Gy}(20-41.60 \mathrm{~Gy})$ [15]. Nevertheless, the use of the linear-quadratic model for doses per fraction greater than 5-6 Gy is debatable and should be assessed with caution. Veeravagu et al. treated 11 IMMs with CyberKnife ${ }^{\bullet}$, with a median dose of 21 Gy (range: 14-27 Gy) with a median number of 3 fractions (range: 1-5). They observed clinical improvement in $11 \%$ and stable symptomatology in $44 \%$ of the patients. They observed no complete response on imaging and partial response in $22 \%$. The $\mathrm{BED}_{10}$ delivered was 35.70 Gy, which may explain the results in terms of LC [16]. Barrie et al. delivered a dose of $25 \mathrm{~Gy}$ in five fractions to one patient. They observed clinical stability and radiological disease progression $\left(\mathrm{BED}_{10}=37.50 \mathrm{~Gy}\right)$ [14]. Often, radiological follow-up data are not available, and $\mathrm{LC}$ is not reported because of the poor prognosis of these pathologies. This makes it difficult to compare the fractionation data and clinical results. Furthermore, our series, which is one of the largest series to date, is the first to describe dosimetric data according to ICRU 91 recommendations.

All lesions in our analysis were treated with CyberKnife ${ }^{\bullet}$. However, SBRT can be performed using different techniques. According to the ICRU Report 91, SBRT is defined as the administration of high doses per fraction, which must be extremely precise and reproducible [26]. It is an extremely precise irradiation technique, with control of the target and its movements, making it possible to deliver high fractional doses to the tumor by limiting the dose to the organs at risk (OAR) $[27,28]$. Hernàndez-Duràn et al., in a systematic review published in 2015, including six studies evaluating SBRT of intramedullary lesions (primary and secondary), reported that the majority of the lesions were treated with CyberKnife ${ }^{\oplus}$ (87\%), with no radiationinduced myelopathy in metastatic patients [7]. Radiation-induced myelopathy is a complication of radiation exposure of the $\mathrm{SC}$, which limits the dose that can be administered [5, 6]. The tolerance dose to the spinal cord has been defined based on retrospective series of patients who developed myelopathy from treatment errors or overlapping fields. Baumann et al., evaluated in a review, the incidence of radiationinduced myelopathy after fractioned radiation therapy. At two years of follow up, incidence was $1 \%$ in patients treated at 50-55 Gy and 5\% when treated at 55-60 Gy [29]. Ryu et al., estimated the partial volume tolerance of the human spinal cord at $10 \mathrm{~Gy}$ to the $10 \%$ spinal cord volume, defined as $6 \mathrm{~mm}$ above and below the target [5]. In our review, we didn't identify any reports of radiation-induced clinical complications. However, the mean survival should be considered in this context. Indeed, survival is reduced in these patients, which could potentially lead to bias in the identification of radiation-induced complications. Radionecrotic lesions have been described at autopsy in treated patients. These patients did not have any clinical signs or symptoms. This raises the question to know if these anatomical findings have any clinical value [30]. Overall, this review reveals that the delivery of high doses of radiation to a small volume of spinal cord has been safely performed, with a mean prescription dose of 21,6 Gy, yielding good clinical and radiological tumor control.

In our study, two patients (40\%) died of disease progression (lung cancer). Ehret et al. reported a median OS of 11.2 months, which is up to five times higher than that reported in other studies $[15,16$, 31]. However, in their study, most of the patients were treated for breast cancer and not lung cancer, which may explain the higher OS. Moreover, this finding is also explained by recent improvements in systemic treatments, including immunotherapy and targeted therapies. Despite the diversity of the patients evaluated and the treatments in our study and the heterogeneity of the different studies, it is evident that each case must be evaluated individually, and the treatment modalities were chosen carefully, depending on the patient, disease history, tumor size, localization, and OS. Moreover, the effectiveness of our treatment can be difficult to assess given that histologies were heterogeneous, only two patients had a systemic treatment during SBRT.

The median time from diagnosis of intramedullary metastasis to initiation of radiotherapy was 21 days in our study. Some patients were asymptomatic. However, this treatment is sometimes complex to implement, and the accessibility of this irradiation technique may also be responsible for a delay in management. 
Like all the series on this subject, our study had limitations related to its retrospective nature, limited number of patients, and limited follow-up time.

In conclusion, currently, there is no standard of care in SBRT for the management of IMMs. The fractionation scheme is left to the discretion of the physician. The most common patterns found in the literature were 3 -fraction (15 Gy in 3 fractions [9], or 27 Gy in 3 fractions [11, 16]) or 5-fraction (25 Gy in 5 fractions [14]) patterns. Ehret et al. proposed most treatments in a single fraction, a short regimen that can be proposed to maintain quality of life. The choice was done depending on the clinical history, the primary lesion (e.g., case of clear cell renal cell carcinoma, typically radioresistant), neurological symptoms, or tumor volume. It seems difficult to define a standard treatment regimen. Although few, if any, neurological complications have been reported, it is essential to find a compromise between the best efficacy and the risk of neurological complications. The palliative setting must be taken into consideration when planning and choosing the treatment. Reducing overall treatment time is an important point to consider not only for patients with multiple comorbidities. Our results showed satisfactory results in terms of LC for patients who often have limited OS. Microsurgical management remains the standard of care, but SBRT is becoming increasingly important in patients with comorbidities as an alternative to surgery. A randomized controlled trial or prospective data are necessary in this context; however, it is difficult to set up in the context of a rare pathology.

\section{Acknowledgments}

We would like to thank Editage (www.editage.com) for English language editing.

\section{Authors' contributions}

DP, RMA, FLT, and XM helped supervise the project and interpret the data. MT made substantial contribution to acquisition of data and wrote the paper. All authors discussed the results and commented on the final manuscript.

\section{Funding}

Nuovo-Soldati for Research Cancer

\section{Availability of data and materials}

The datasest used and analysed during the current study are available from the corresponding author on reasonable request.

\section{Declarations}

\section{Ethics approval and consent to participate}

Ethical approval for this study was not required. The study complies with the reference methodology MR004 adopted by the French Data Protection Authority (CNIL). None of the patients had objected to the use of their clinical data for research purposes.

Consent for publication

Not applicable.

\section{Competing interests}

The authors declare that there is no competing interests.

\section{Author details}

'Département Universitaire de Radiothérapie - Centre Oscar Lambret, Lille, France. ${ }^{2}$ Centre de Recherche du Centre Hospitalier Universitaire de Montréal (CRCHUM), QC, Montréal, Canada. ${ }^{3}$ CRIStAL UMR CNRS 9189, Lille University, Lille, France.

Received: 13 July 2021 Accepted: 14 October 2021

Published online: 30 October 2021

\section{References}

1. Payer S, Mende KC, Westphal M, Eicker SO. Intramedullary spinal cord metastases: an increasingly common diagnosis. Neurosurg Focus. 2015;39(2): E15. https://doi.org/10.3171/2015.5.FOCUS15149.

2. Hamilton AJ, Lulu BA, Fosmire H, Gossett L. LINAC-based spinal stereotactic radiosurgery. Stereotact Funct Neurosurg. 1996;66(1-3):1-9. https://doi.org/1 $0.1159 / 000099658$.

3. Gerszten PC, Burton SA, Ozhasoglu C, Welch WC. Radiosurgery for spinal metastases: clinical experience in 500 cases from a single institution. Spine. 2007;32(2):193-9. https://doi.org/10.1097/01.brs.0000251863.76595.a2.

4. Gagnon GJ, Nasr NM, Liao JJ, Molzahn I, Marsh D, McRae D, et al. Treatment of spinal tumors using cyberknife fractionated stereotactic radiosurgery: pain and quality-of-life assessment after treatment in 200 patients. Neurosurgery. 2009;64(2):297-306; discussion 306-307. https://doi.org/10.122 7/01.NEU.0000338072.30246.BD.

5. Ryu S, Jin J-Y, Jin R, Rock J, Ajlouni M, Movsas B, et al. Partial volume tolerance of the spinal cord and complications of single-dose radiosurgery. Cancer. 2007;109(3):628-36. https://doi.org/10.1002/cncr.22442.

6. Gibbs IC, Patil C, Gerszten PC, Adler JR, Burton SA. Delayed radiationinduced myelopathy after spinal radiosurgery. Neurosurgery. 2009;64(2 Suppl):A67-72. https://doi.org/10.1227/01.NEU.0000341628.98141.B6.

7. Hernández-Durán S, Hanft S, Komotar RJ, Manzano GR. The role of stereotactic radiosurgery in the treatment of intramedullary spinal cord neoplasms: a systematic literature review. Neurosurg Rev. 2016;39(2):175-83; discussion 183. https://doi.org/10.1007/s10143-015-0654-y.

8. International Commission on Radiation Units and Measurements (ICRU) [Internet]. [cité 24 févr 2021]. Disponible sur: https://icru.org/content/ reports/icru-report-91-prescribing-recording-and-reporting-of-stereotactictreatments-with-small-photon-beams

9. Parikh S, Heron DE. Fractionated radiosurgical management of intramedullary spinal cord metastasis: a case report and review of the literature. Clin Neurol Neurosurg. 2009;111(10):858-61. https://doi.org/10.101 6/.clineuro.2009.06.008.

10. Dewas S, Le Rhun E, Duhem R, Dansin E, Prevost B, Lartigau E. Solitary intramedullary metastasis from malignant pleural mesothelioma treated with CyberKnife: A case report. Rev Neurol. 2011;167(2):185-6. https://doi. org/10.1016/.j.neurol.2010.07.028.

11. Lieberson RE, Veeravagu A, Eckermann JM, Doty JR, Jiang B, Andrews R, et al. Intramedullary spinal cord metastasis from prostate carcinoma: a case report. J Med Case Rep. 2012;6(1):139. https://doi.org/10.1186/1752-19476-139.

12. Mori Y, Kawamura T, Ohshima Y, Takeuchi A, Mori T, Ishiguchi T. Stereotactic radiotherapy for cervical spinal intramedullary metastasis and multiple brain metastases: a case report. Cureus. 2016;8:e590. https://doi.org/10.7759/ cureus.590.

13. Garcia R, Sallabanda K, Santa-Olalla I, Lopez Guerra JL, Avilés L, Sallabanda $M$, et al. Robotic radiosurgery for the treatment of intramedullary spinal cord metastases: a case report and literature review. Cureus. 2016;8:e609. https://doi.org/10.7759/cureus.609.

14. Barrie U, Elguindy M, Pernik M, Adeyemo E, Aoun SG, Hall K, et al. Intramedullary spinal metastatic renal cell carcinoma: systematic review of disease presentation, treatment, and prognosis with case illustration. World Neurosurgery. 2020;134:584-93. https://doi.org/10.1016/j.wneu.2019.11.056.

15. Shin DA, Huh R, Chung SS, Rock J, Ryu S. Stereotactic spine radiosurgery for intradural and intramedullary metastasis. Neurosurg Focus. 2009;27(6):E10. https://doi.org/10.3171/2009.9.FOCUS09194.

16. Veeravagu A, Lieberson RE, Mener A, Chen Y-R, Soltys SG, Gibbs IC, et al. Cyberknife stereotactic radiosurgery for the treatment of intramedullary 
spinal cord metastases. J Clin Neurosci. 2012;19(9):1273-7. https://doi.org/1 0.1016/j.jocn.2012.02.002

17. Ehret $F$, Senger $C$, Kufeld M, Fürweger C, Kord M, Haidenberger $A$, et al. Image-guided robotic radiosurgery for the Management of Intramedullary Spinal Cord Metastases-a Multicenter Experience. Cancers. 2021;13(2):297. https://doi.org/10.3390/cancers13020297.

18. Kotecha R, Mehta MP, Chang EL, Brown PD, Suh JH, Lo SS, et al. Updates in the management of intradural spinal cord tumors: a radiation oncology focus. Neuro-Oncology. 2019;21(6):707-18. https://doi.org/10.1093/neuonc/ noz014.

19. Strickland BA, McCutcheon IE, Chakrabarti I, Rhines LD, Weinberg JS. The surgical treatment of metastatic spine tumors within the intramedullary compartment. J Neurosurg Spine. 2018;28(1):79-87. https://doi.org/10.31 71/2017.5.SPINE161161.

20. Dam-Hieu P, Seizeur R, Mineo J-F, Metges J-P, Meriot P, Simon H. Retrospective study of 19 patients with intramedullary spinal cord metastasis. Clin Neurol Neurosurg. 2009;111(1):10-7. https://doi.org/10.1016/ j.clineuro.2008.06.019.

21. Saeed H, Patel R, Thakkar J, Hamoodi L, Chen L, Villano JL. Multimodality therapy improves survival in intramedullary spinal cord metastasis of lung primary. Hematol Oncol Stem Cell Ther. 2017;10(3):143-50. https://doi.org/1 0.1016/j.hemonc.2017.07.003.

22. Schiff $D, O$ O'Neill BP. Intramedullary spinal cord metastases: clinical features and treatment outcome. Neurology. 1996;47(4):906-12. https://doi.org/1 0.1212/WNL.47.4.906.

23. Hashii H, Mizumoto M, Kanemoto A, Harada H, Asakura H, Hashimoto T, et al. Radiotherapy for patients with symptomatic intramedullary spinal cord metastasis. J Radiat Res. 2011;52(5):641-5. https://doi.org/10.1269/jrr.10187.

24. Chow E, Hoskin P, Mitera G, Zeng L, Lutz S, Roos D, et al. Update of the international consensus on palliative radiotherapy endpoints for future clinical trials in bone metastases. Int J Radiat Oncol Biol Phys. 2012;82(5): 1730-7. https://doi.org/10.1016/j.ijrobp.2011.02.008.

25. Sze WM, Shelley M, Held I, Mason M. Palliation of metastatic bone pain: single fraction versus multifraction radiotherapy - a systematic review of the randomised trials. Cochrane Database Syst Rev. 2004;2:CD004721.

26. Report 91. J ICRU 14(2):1-160.

27. Papież L, Timmerman R, Desrosiers C, Randall M. Extracranial stereotactic Radioablation physical principles. Acta Oncol. 2003;42(8):882-94. https://doi. org/10.1080/02841860310013490.

28. Potters L, Kavanagh B, Galvin JM, Hevezi JM, Janjan NA, Larson DA, et al. American Society for Therapeutic Radiology and Oncology (ASTRO) and American College of Radiology (ACR) practice guideline for the performance of stereotactic body radiation therapy. Int J Radiat Oncol Biol Phys. 2010;76(2):326-32. https://doi.org/10.1016/j.jijobp.2009.09.042.

29. Baumann M, Budach V, Appold S. Radiation tolerance of the human spinal cord. Strahlenther Onkol. 1994;170(3):131-9.

30. Koga T, Morita A, Maruyama K, Tanaka M, Ino Y, Shibahara J, et al. Longterm control of disseminated pleomorphic xanthoastrocytoma with anaplastic features by means of stereotactic irradiation. Neuro-Oncology. 2009;11(4):446-51. https://doi.org/10.1215/15228517-2008-112.

31. Goyal A, Yolcu Y, Kerezoudis P, Alvi MA, Krauss WE, Bydon M. Intramedullary spinal cord metastases: an institutional review of survival and outcomes. J Neuro-Oncol. 2019;142(2):347-54. https://doi.org/10.1007/s11060-019-031 05-2.

\section{Publisher's Note}

Springer Nature remains neutral with regard to jurisdictional claims in published maps and institutional affiliations.

Ready to submit your research? Choose BMC and benefit from:
- fast, convenient online submission
- thorough peer review by experienced researchers in your field
- rapid publication on acceptance
- support for research data, including large and complex data types
- gold Open Access which fosters wider collaboration and increased citations
- maximum visibility for your research: over 100M website views per year
At BMC, research is always in progress.
Learn more biomedcentral.com/submissions

